\title{
Stable isotopes reveal life history polymorphism in the coastal fish Apogon notatus
}

\author{
Kayoko Fukumori ${ }^{1,2, *}$, Noboru Okuda ${ }^{2}$, Hideki Hamaoka ${ }^{1}$, Toru Fukumoto ${ }^{3}$, \\ Daisuke Takahashi ${ }^{1,4}$, Koji Omori ${ }^{1}$
}

\footnotetext{
${ }^{1}$ Center for Marine Environmental Studies (CMES), Ehime University, 2-5 Bunkyo-cho, Matsuyama 790-8577, Japan

${ }^{2}$ Center for Ecological Research, Kyoto University, 509-3, 2-chome, Hirano, Otsu, Shiga 520-2113, Japan

${ }^{3}$ Saga Prefectural Genkai Fisheries Research and Development Center, 6966 Nagoya, Chinzei-cho, Karatsu 847-0401, Japan

${ }^{4}$ Present address: Hydrospheric Atmospheric Research Center, Nagoya University, Furo-cho, Chikusa-ku, Nagoya 464-8601, Japan
}

\begin{abstract}
In the coastal marine fish Apogon notatus most individuals emigrate from the neritic breeding ground in winter and return there in the following spring (migratory type), while some individuals reside in the neritic habitat throughout the year (resident type). In the present study, we conducted carbon and nitrogen stable isotope analysis to estimate their winter migration routes and to elucidate the underlying spatial heterogeneity in the food web structure of the coastal ecosystem, and compared the results with those of $A$. semilineatus, a deepwater congener. A. notatus fed on a variety of zooplankton and zoobenthos in the neritic habitat, whereas $A$. semilineatus fed on pelagic mysids exclusively. The former showed more enriched $\delta^{13} \mathrm{C}$ than did the latter, indicating strong reliance on benthic production. Such a difference in stable isotope ratio was attributed to spatial heterogeneity in the coastal food web structure: benthic microalgal production predominates in the neritic food web, while the pelagic deepwater food web is characterized by phytoplankton production. After returning from winter migration, A. notatus showed marked depletion of $\delta^{13} \mathrm{C}$ compared to its non-migratory counterpart residing in the neritic habitat. Thereafter, the migratory type showed enrichment of $\delta^{13} \mathrm{C}$ during its stay in the neritic breeding ground, approaching that of the resident type. The results suggest that most $A$. notatus migrated to the deepwater habitat and spent a couple of winter months there. Stable isotope analysis revealed that life history polymorphism (i.e. migratory and resident types) exists in the $A$. notatus population.
\end{abstract}

KEY WORDS: Migration $\cdot$ Stable isotope analysis $\cdot$ Dietary analysis $\cdot$ Non-diadromous fish $\cdot$ Food web

\section{INTRODUCTION}

Many animals migrate among different habitats diurnally, seasonally or at a given stage of their life histories. Research of their migration routes is very important in understanding material cycling within and across ecosystems because migratory animals contribute to the transport of energy and nutrients among habitats through feeding and excretion activities. However, we often encounter difficulties in tracking migration routes because some animals migrate long distances or underwater, as in birds and fishes. Dietary analysis is a conventional approach to determine changes in habitatrelated food items of a focal animal during migration.
However, this method provides no quantitative information because it only gives a 'snapshot' of an individual's feeding habit and may underestimate the relative importance of easily digestible food items in its diet (Bradstreet 1980, Gaston \& Nettleship 1981).

Stable isotope analysis has been increasingly used to provide time-integrated information of food sources for consumers and their trophic relationships in the food web. In the food web a consumer's carbon isotope ratio is a reflection of a signature of primary producers (DeNiro \& Epstein 1978, Fry \& Sherr 1984), and its nitrogen isotope ratio indicates its trophic level (Minagawa \& Wada 1984). Stable isotope ratios in animal tissues are gradually replaced by metabolic turnover, 
integrating dietary information over the long term. Therefore, using stable isotope analysis, we can estimate the feeding experience of focal animals for the past several weeks to months (Hobson 1999).

Mobile animals usually show spatial variation in their isotope ratios, which are peculiar to respective ecosystems via biogeochemical processes (DeNiro \& Epstein 1981, Webster et al. 2002, Wissel \& Fry 2005). Because of this spatial heterogeneity, when animals migrate between isotopically distinct ecosystems, isotope information of their previous feeding locations is recorded in their tissue (Tieszen \& Boutton 1988, Hobson \& Clark 1992). Based on this property, stable isotope analysis has been hitherto used as a powerful tool to identify birthplace and migration routes of animals (e.g. Peterson \& Fry 1987, Tieszen \& Boutton 1988, Michener \& Schell 1994, Hansson et al. 1997, Burton \& Koch 1999, Hobson 1999, Cherel et al. 2000, Maruyama et al. 2001, Webster et al. 2002).

Apogon notatus (Pisces: Apogonidae) is a marine cardinalfish found in the coastal waters of the northwestern Pacific. In this species females maintain their territories on neritic boulder areas during prebreeding (March to April) and breeding (May to September) (Okuda 1999). After the last spawning in the season, they abandon their territories and form large shoals. In winter most individuals disappear from the neritic breeding ground, while some remain. In the following spring the disappearing fish return to their neritic breeding ground, and females, in particular, reestablish their territories. Remarkably, most females that return to their breeding ground settle at the same breeding territory as the previous season (Okuda 1999).

In diadromous fishes, such as osmerids and salmonids, which migrate between freshwater and marine ecosystems, many studies using stable isotope analysis to estimate migration routes have been conducted (Doucett et al. 1999a, McCarthy \& Waldron 2000, Cunjak et al. 2005, Hicks et al. 2005). These are good examples for using isotope ratios to elucidate animal migratory behavior, taking advantage of differences in isotopic composition of the food webs between freshwater and marine ecosystems.

The coastal ecosystem is a continuum of spatially distinct food webs, namely, neritic and pelagic food webs. These 2 food webs are characterized by their production structure. In the neritic habitat where sufficient light reaches the bottom, benthic microalgae play an important role in the food web (Borum \& SandJensen 1996, Jahnke et al. 2000, Takai et al. 2002, Okuda et al. 2004). In the pelagic habitat or its aphotic layer (i.e. deepwater habitat), in contrast, phytoplankton-derived organic matter is the major basal food source for consumers because benthic microalgae cannot grow on the bottom (McGlathery et al. 2001, Gazeau et al. 2004).

The neritic and pelagic food webs also differ in their isotopic signatures. In general, benthic microalgae tend to be enriched in $\delta^{13} \mathrm{C}$ relative to phytoplankton due to the $\mathrm{CO}_{2}$ boundary layer effect, which causes diffusion limitation to benthic algal cells (France 1995a, Hecky \& Hesslein 1995). The neritic food web is thus more $\delta^{13} \mathrm{C}$-enriched than the pelagic food web, resulting in the marked difference in animal carbon isotope ratios between these 2 food webs (France 1995b). Based on such a spatial isotopic heterogeneity in the coastal ecosystem, stable isotope analysis is expected to provide information on the migratory behavior of non-diadromous coastal fishes that migrate between neritic and pelagic (or its deepwater) habitats.

In the present study, first, we compared carbon and nitrogen stable isotope ratios between 2 cardinalfishes, Apogon notatus and A. semilineatus, which live mainly in neritic and deepwater habitats, respectively, in order to characterize the production structure in the coastal ecosystems. Second, we focused on intraspecific variation in migratory behavior of neritic $A$. notatus, most of which emigrate from the neritic breeding ground in winter and return there in spring (hereafter, migratory type) and some of which reside in the neritic habitat throughout the year (hereafter, resident type). We estimated the migration routes of this fish by comparing isotope values and feeding habits between the 2 types and by referring to the deepwater congener A. semilineatus.

\section{MATERIALS AND METHODS}

Monthly census. We conducted a field survey in Uwa Sea fronting the southwestern part of Shikoku Island, Japan (Fig. 1). We set a quadrat measuring $10 \times 20 \mathrm{~m}$ on the neritic boulder area that had a depth of 3.6 to $8.5 \mathrm{~m}$ at Murote Beach (Fig. 1) and conducted monthly censuses with the aid of SCUBA for 4 to $5 \mathrm{~d}$ from April 2000 to March 2001, except June when we conducted the census for only $1 \mathrm{~d}$. In the quadrat we counted the number of Apogon notatus and recorded water temperature. In winter we conducted an extensive census by thoroughly diving around areas (ca. $3.6 \mathrm{~km}^{2}$ ) less than $30 \mathrm{~m}$ deep at Murote Beach (Fig. 1) to monitor fish that disappeared from the quadrat.

Sample collection. We collected Apogon notatus specimens at Murote Beach every 2 mo from October 2003 to June 2004, using a seine and hand net with the aid of SCUBA or by fishing, for stable isotope analysis and stomach content analysis. Additional sampling was conducted in March 2004 when migratory A. notatus started to return to the neritic breeding ground. In 


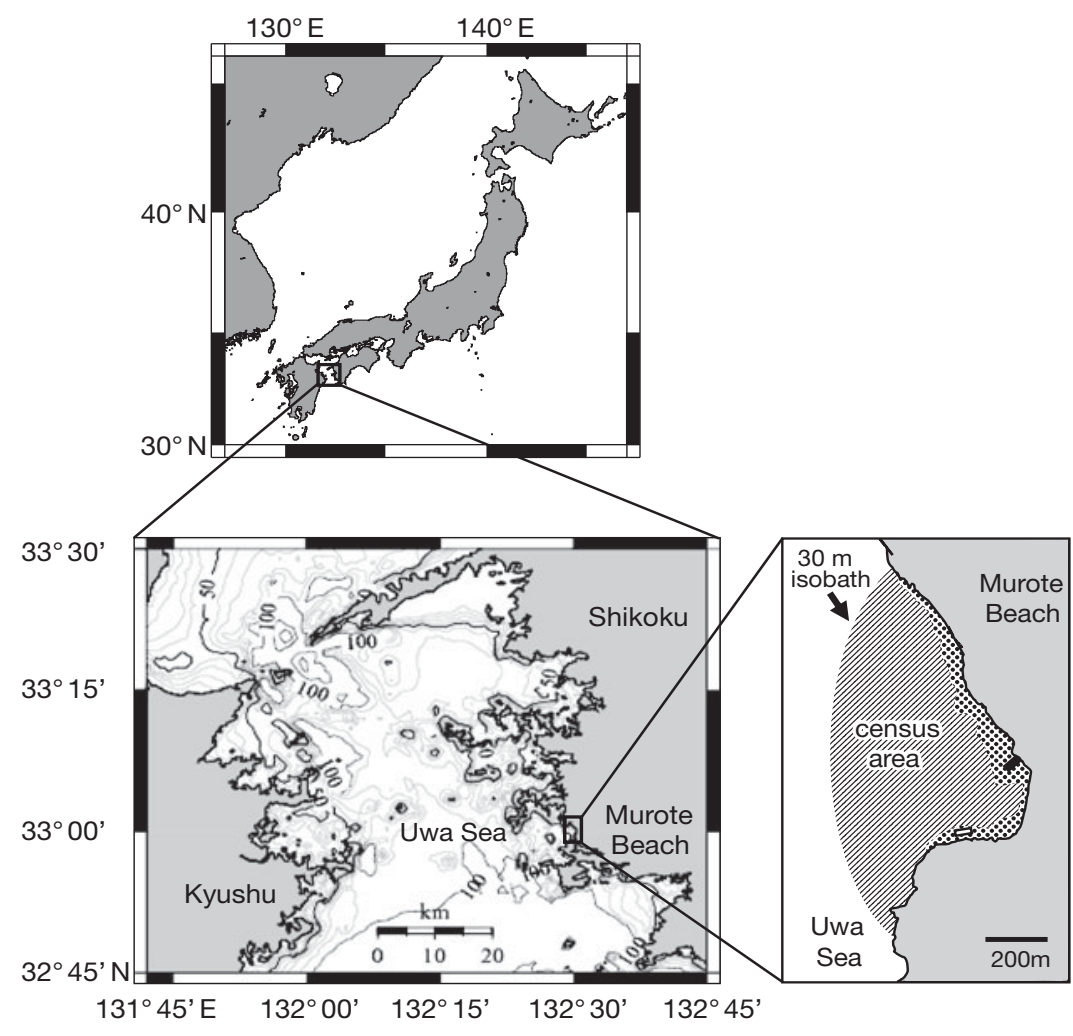

Fig. 1. Location of the study site Murote Beach. The quadrat (white bar) was set on the boulder area (dotted). Extensive censuses were conducted throughout the bay (hatched). In midwinter resident individuals were found only around a breakwater (black bar)

midwinter when water temperature was lowest, most A. notatus disappeared from the study site, while some resided around a breakwater that provided shelter (Fig. 1). We regarded the former as migratory type and the latter as resident type. When the migratory type returned to the neritic breeding ground in March, it was not possible to discriminate them from the resident type by their appearances. However, since A. notatus shows strong site fidelity after establishing its breeding territory (Okuda 1999), individuals inhabiting the breakwater were considered to be resident.

We collected 20 specimens each of migratory and resident types in all sampling months except February when only the resident type was available. Of these 20 specimens, 10 were used for stable isotope analysis. Prior to the analysis we excised muscle tissues from the dorsal part of the lateral body after measuring standard length (SL) to the nearest $0.1 \mathrm{~mm}$. The isotopic samples were frozen until analysis. For stomach content analysis, we dissected all specimens and preserved their stomach contents in 5\% formalin. For these specimens we examined their sex by gonadal inspection. The sex ratios (male:female) of Apogon notatus were not different between migratory (35:26) and resident (38:22) types $\left(\chi^{2}=0.45, p=0.79\right)$.
In comparison with neritic Apogon notatus, the deepwater congener $A$. semilineatus was collected by fishery trawls in pelagic deep waters (40 to $60 \mathrm{~m}$ depth) of Uwa Sea (Fig. 1). Sample collection was conducted every $2 \mathrm{mo}$, in parallel with that of A. notatus. We scheduled a regular sample collection of $A$. semilineatus in January but not February because we were concerned that bad weather would prevent fishery operations. We used all specimens for stomach content analysis and 10 specimens per month for stable isotope analysis. Body size measurement and sample preparation were the same as for A. notatus.

To characterize the coastal food web configuration using stable isotope analysis, we collected potential prey of these 2 cardinalfishes and primary producers as their possible carbon sources at Murote Beach in June 2004. In our study site the dominant primary producers were phytoplankton, benthic microalgae and macroalgae. For phytoplankton we collected particulate organic matter (POM) using a plankton net with $100 \mu \mathrm{m}$ mesh. POM was filtered through a $200 \mu \mathrm{m}$ mesh net to remove mesozooplankton. Microscopic observations confirmed that the POM consisted almost entirely of phytoplankton. We regarded this size fraction (100 to $200 \mu \mathrm{m})$ of POM as phytoplankton. POM sampling was conducted in triplicate $(\mathrm{N}=3)$. Benthic microalgae were scraped off each of 5 stones in shallow waters using a brush, and its particulate matter was screened with the $100 \mu \mathrm{m}$ mesh net to remove meiobenthos $(\mathrm{N}=5)$. POM and benthic microalgal samples were GF/A filtered and precombusted at $550^{\circ} \mathrm{C}$ for $3 \mathrm{~h}$. Three common macroalgal species, the green macroalga Caulerpa brachypus $(\mathrm{N}=6)$, the red macroalga Meristotheca papulosa $(\mathrm{N}=6)$ and the brown macroalga Sargassum piluliferum $(\mathrm{N}=6)$, were collected in shallow waters. Zooplankton was collected by towing a $300 \mu \mathrm{m}$ mesh plankton net vertically from the bottom to surface layers. Hypoplankton was collected by towing the $300 \mu \mathrm{m}$ mesh plankton net immediately above the bottom. To collect zoobenthos, sediments were collected with an Ekman-Berge bottom sampler. These zooplankton and zoobenthos were collected at the sites where an average depth was $25.7 \mathrm{~m}$ (22.3 to $28.2 \mathrm{~m}, \mathrm{~N}=5$ ). We sorted zoobenthos with a $1 \mathrm{~mm}$ mesh screen and a $300 \mu \mathrm{m}$ mesh net: the former was defined as macrobenthos and the latter as meiobenthos. All biological samples were identified at least to the order level by microscopic observation in the lab- 
oratory. These samples were frozen until stable isotope analysis.

Dietary analysis and stable isotope analysis. We conducted stomach content analysis of a total of 220 specimens of Apogon notatus and 100 specimens of A. semilineatus to compare feeding habits between neritic $A$. notatus and deepwater $A$. semilineatus or between migratory and resident types of A. notatus. Of these, 19 migratory and 54 resident specimens of $A$. notatus and 46 specimens of $A$. semilineatus had empty stomachs, so they were excluded from the analysis. We sorted prey items and classified them at least to the class level and, if possible, to the order level. After counting the number of prey items, we dried them at $60^{\circ} \mathrm{C}$ for $24 \mathrm{~h}$ and weighed them in bulk for each taxonomic group. We used 3 indices to represent their feeding habits: percentage frequency of each prey taxon $(\% F)$ with respect to the total number of fish specimens, the percentage number of each prey taxon with respect to the total number of prey items $(\% N)$ and the percentage weight of each prey taxon with respect to the total weight of prey items $(\% W)$. The latter 2 indices were calculated by pooling all specimens of A. semilineatus, migratory A. notatus or resident $A$. notatus for each month.

We measured stable carbon and nitrogen isotope ratios of migratory and resident types of neritic Apogon notatu, and of deepwater A. semilineatus. We also measured the isotope ratios of their potential prey. For fish specimens and their large prey, we used muscle tissues as isotopic samples. For small prey, we used whole-body or bulk samples. All isotopic samples were dried at $60^{\circ} \mathrm{C}$ for $24 \mathrm{~h}$, ground to powder form and immersed in chloroform:methanol (2:1) solution for $24 \mathrm{~h}$ to remove lipids. For primary producers, ground samples were exposed to $12 \mathrm{~N} \mathrm{HCl}$ vapor for $24 \mathrm{~h}$ to remove carbonate carbon. Carbon and nitrogen stable isotope ratios were measured with a mass spectrometer (ANCA-SL, PDZ Europa). Isotopic notations of carbon $\left(\delta^{13} \mathrm{C}\right)$ and nitrogen $\left(\delta^{15} \mathrm{~N}\right)$ are expressed as per mille deviation from the standard with the following equation:

$$
\delta^{13} \mathrm{C}, \delta^{15} \mathrm{~N}=\left[R_{\text {sample }} / R_{\text {standard }}-1\right] \times 1000(\% \text { ) }
$$

where $R={ }^{13} \mathrm{C} /{ }^{12} \mathrm{C}$ or ${ }^{15} \mathrm{~N} /{ }^{14} \mathrm{~N}$. Pee Dee belemnite (PDB) limestone carbonate and atmospheric nitrogen $\left(\mathrm{N}_{2}\right)$ were used as standards for carbon and nitrogen isotope ratios, respectively.

Statistical analysis. To depict the food web configuration on the isotope map, carbon and nitrogen isotope values were averaged and plotted for each prey taxon. Using these isotope data, we performed hierarchical cluster analysis with Ward's minimum variance method in order to classify each prey taxon into a given feeding functional group within the coastal food web.
For food web analysis, we assumed that the trophic enrichment factor was $3.4 \%$ for $\delta^{15} \mathrm{~N}$ and $0.8 \%$ for $\delta^{13} \mathrm{C}$ (France \& Peters 1997, Vander Zanden \& Rasmussen 1999).

Prior to the statistical test between type and seasonal variations of $\delta^{13} \mathrm{C}$ and $\delta^{15} \mathrm{~N}$ in Apogon notatus, we checked the size dependence of their isotope values. Because both $\delta^{13} \mathrm{C}$ and $\delta^{15} \mathrm{~N}$ are significantly correlated with SL (Pearson's correlation, $\delta^{13} \mathrm{C}: \mathrm{r}=0.4, \mathrm{p}<0.001$; $\left.\delta^{15} \mathrm{~N}: \mathrm{r}=0.6, \mathrm{p}<0.001\right)$, we used 2-way ANCOVA incorporating 2 factors, season(month) and life history type (migratory or resident) and a covariate, SL, provided that either factor did not interact with SL. We used the contrast method for post hoc comparisons to examine isotopic difference between life history types in each month.

Although we a priori classified Apogon notatus inhabiting the breakwater into resident type based on strong site fidelity, there is a possibility that migratory fish that newly settled there were misclassified into the resident type. To estimate the probability of such a misclassification (i.e. incorrect discrimination rate), we performed discriminant analysis using data in March, assuming that migratory fish would have thoroughly different isotopic signatures from those of resident fish in March, just after their return from the pelagic deep water. The linear combination for a discriminant analysis was derived from an equation that takes the form:

$$
z=\mathrm{a}_{0}+\mathrm{a}_{1} x_{1}+\mathrm{a}_{2} x_{2}+\ldots+\mathrm{a}_{\mathrm{n}} x_{\mathrm{n}}
$$

where $z$ is the discriminant score, $\mathrm{a}_{i}(i=1,2, \ldots, \mathrm{n})$ is the discriminant coefficient, $x$ is the independent variable and $\mathrm{a}_{0}$ is a constant.

We incorporated their $\delta^{13} \mathrm{C}$ and $\delta^{15} \mathrm{~N}$ as independent variables into the model. Considering the incorrect discrimination rate calculated in March, we also performed the discriminant analysis for other months to examine whether or not their isotopic signatures were effective in discriminating between 2 life history types.

Since the sampling schedules for Apogon notatus and $A$. semilineatus did not completely match, we could not simply compare these 2 species. For reference, nevertheless, isotopic signatures of $A$. semilineatus are visualized by their discriminant scores calculated from the above model.

For descriptive purposes, means $\pm \mathrm{SD}$ are given. All $\mathrm{p}$ values are 2-tailed.

\section{RESULTS}

\section{Seasonal migration}

In April some Apogon notatus settled in the neritic habitat to establish their breeding territories, and the 


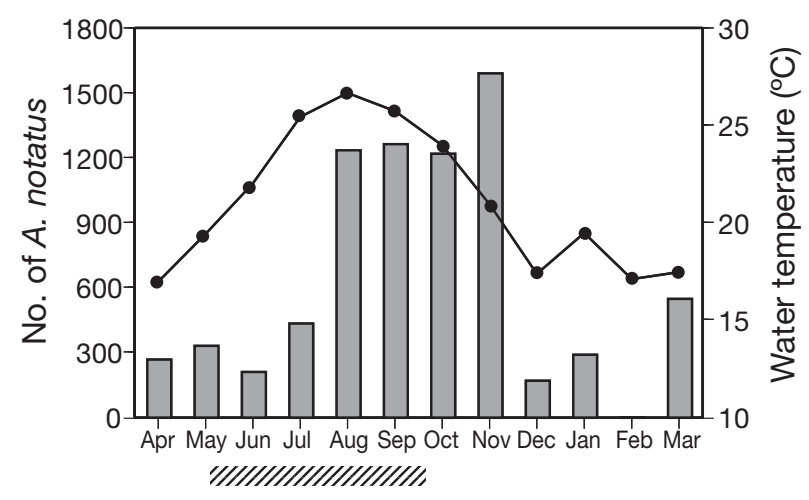

Fig. 2. Monthly changes in the average number of Apogon notatus (bars) found in the quadrat $\left(10 \times 20 \mathrm{~m}^{2}\right)$ and in water temperature (๑). The horizontal hatched bar indicates duration of the breeding season

number of breeding fish increased in summer (Fig. 2). In September, the last breeding month, all fish ceased to maintain their breeding territories, forming large shoals. The fish stayed on the breeding ground until November, and most of them disappeared from the neritic habitat in December when water temperature decreased to less than $20^{\circ} \mathrm{C}$. In February (midwinter), we did not find any $A$. notatus in the neritic habitat except around a breakwater (Fig. 1). In March, however, many fish returned to the neritic breeding ground (Fig. 2).

\section{Feeding habit}

Prey items of neritic Apogon notatus and deepwater A. semilineatus are shown in Table 1. Most individuals of A. notatus fed on benthic amphipods, such as gammarids and caprellids, while calanoid copepods were the most predominant prey item in terms of number. In terms of weight the major prey item was fish larvae. For A. semilineatus, in contrast, mysids were the most important prey item, as shown by all 3 dietary indices.

Seasonal changes in feeding habits of migratory and resident Apogon notatus and $A$. semilineatus are shown in Fig. 3. A. semilineatus fed mainly on mysids throughout the year (Fig. 3c), while A. notatus showed marked seasonal variation in feeding habits (Fig. 3a,b). Migratory A. notatus frequently fed on decapod larvae in October, which accounted for $70 \%$ of its total prey by weight. In December, immediately before migration, the migratory type fed mainly on decapod adults and appendicularians, whereas the resident type fed on large quantities of calanoid copepods and Chaetognatha. In March and April, when the migratory type returned to their breeding ground, fish larvae and benthic amphipods were the major prey for both migratory and resident types. Thereafter, their feeding habits showed a similar pattern.

\section{Coastal food web}

$\delta^{13} \mathrm{C}$ and $\delta^{15} \mathrm{~N}$ stable isotope ratios of Apogon notatus, A. semilineatus and their potential prey are shown in Fig. 4. The $\delta^{15} \mathrm{~N}$ and $\delta^{13} \mathrm{C}$ were $12.6 \pm 0.5$ and $-16.4 \pm$ $0.4 \%$ or $A$. notatus, respectively, and $12.1 \pm 0.5$ and $-16.9 \pm 0.4 \%$ o for $A$. semilineatus, respectively. Both isotope ratios were significantly more depleted for A. semilineatus than for $A$. notatus (unpaired $t$-test, $\delta^{13} \mathrm{C}: t_{1,175}=$ $\left.7.76, \mathrm{p}<0.001, \delta^{15} \mathrm{~N}: t_{1,175}=6.79, \mathrm{p}<0.001\right)$. Based on the $\delta^{13} \mathrm{C}$ and $\delta^{15} \mathrm{~N}$, prey were classified into 5 feeding functional groups by cluster analysis (Fig. 4), the criterion for which was set at less than 6.0 of the squared Euclidean

Table 1. Feeding habits of Apogon notatus and A. semilineatus living in neritic and deepwater habitats, respectively, in Uwa Sea. Dietary data are expressed as percentage frequency $(\% F)$, percentage no. $(\% N)$, and percentage weight $(\% W)$ of each prey taxon

\begin{tabular}{|c|c|c|c|c|c|c|}
\hline \multirow[t]{2}{*}{ Prey item } & \multicolumn{3}{|c|}{ A. notatus } & \multicolumn{3}{|c|}{ A. semilineatus } \\
\hline & $\% F$ & $\% N$ & $\% W$ & $\% F$ & $\% N$ & $\% W$ \\
\hline \multicolumn{7}{|l|}{ Copepoda } \\
\hline Calanoida & 9.3 & 40.6 & 12.8 & 8.7 & 7.3 & 0.1 \\
\hline Poecilostomatoida & 0.7 & 0.0 & 0.0 & 0.0 & 0.0 & 0.0 \\
\hline \multicolumn{7}{|l|}{ Isopoda } \\
\hline Flabellifera & 2.6 & 0.2 & 9.6 & 4.3 & 2.4 & 1.8 \\
\hline Mysida & 7.2 & 0.7 & 0.5 & 52.2 & 56.9 & 70.4 \\
\hline Cumacea & 1.7 & 0.1 & 0.1 & 0.0 & 0.0 & 0.0 \\
\hline \multicolumn{7}{|l|}{ Amphipoda } \\
\hline Gammaridea (planktonic) & 4.3 & 7.5 & 0.7 & 1.4 & 4.1 & 0.0 \\
\hline Gammaridea (benthic) & 23.9 & 20.2 & 9.6 & 10.1 & 10.6 & 0.7 \\
\hline Caprellidea & 13.6 & 3.6 & 8.0 & 0.0 & 0.0 & 0.0 \\
\hline \multicolumn{7}{|l|}{ Eucarida } \\
\hline Euphausiacea & 0.5 & 0.0 & 0.1 & 2.9 & 3.3 & 0.5 \\
\hline \multicolumn{7}{|l|}{ Decapoda } \\
\hline Caridea & 8.1 & 3.2 & 3.9 & 5.8 & 5.7 & 1.6 \\
\hline Brachyura & 0.5 & 0.1 & 0.5 & 0.0 & 0.0 & 0.0 \\
\hline Decapod larvae & 8.4 & 1.5 & 3.0 & 1.4 & 1.6 & 0.0 \\
\hline \multicolumn{7}{|l|}{ Polychaete } \\
\hline Phyllodocida & 0.7 & 0.1 & 0.1 & 4.3 & 2.4 & 0.2 \\
\hline \multicolumn{7}{|l|}{ Chaetognatha } \\
\hline Aphregmophora & 5.7 & 14.8 & 6.2 & 0.0 & 0.0 & 0.0 \\
\hline \multicolumn{7}{|l|}{ Appendicularia } \\
\hline Larvacea & 5.7 & 6.9 & 0.8 & 0.0 & 0.0 & 0.0 \\
\hline \multicolumn{7}{|l|}{ Fish } \\
\hline Clupeiformes juvenile & 0.5 & 0.0 & 1.8 & 2.9 & 2.4 & 13.0 \\
\hline Unknown larvae & 6.0 & 0.4 & 35.9 & 4.3 & 2.4 & 7.5 \\
\hline
\end{tabular}




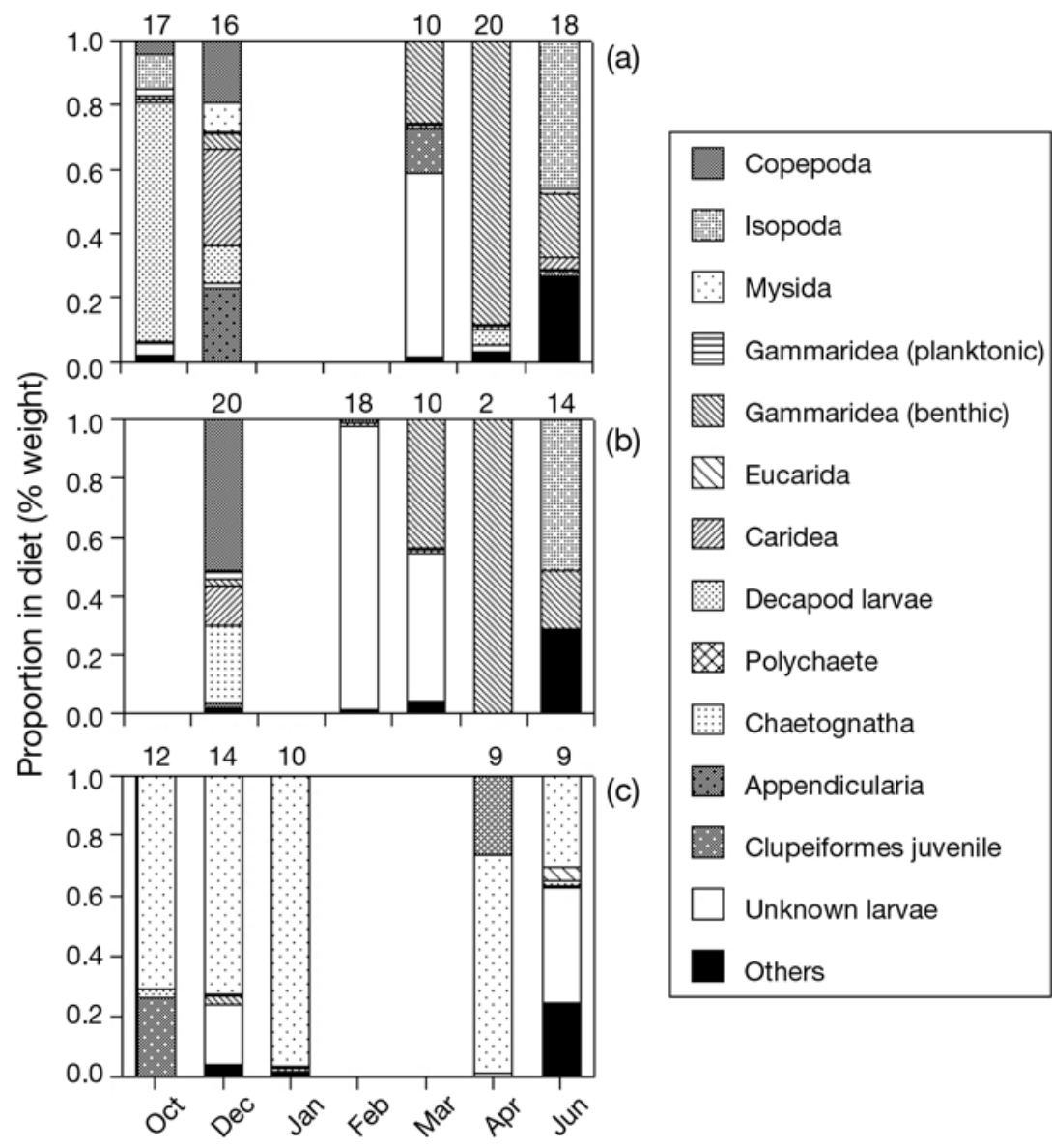

Fig. 3. Seasonal changes of feeding habits indicated by \% weight for (a) migratory and (b) resident types of neritic Apogon notatus and (c) deepwater A. semilineatus. Blanks indicate no specimens or insufficient data of stomach contents (see 'Materials and methods'). Values above bars denote sample sizes benthic invertebrates, such as caprellids and polychaetes. Group D consisted of benthic gammarids and isopods, having the highest $\delta^{13} \mathrm{C}$ and lowest $\delta^{15} \mathrm{~N}$ values. Group E consisted of only mysids and had the most depleted $\delta^{13} \mathrm{C}$. Based on dietary analysis, $A$. semilineatus fed mainly on Group E, while A. notatus had a variety of prey taxa except Group E.

\section{Stable isotopic variation}

Seasonal changes of $\delta^{13} \mathrm{C}$ and $\delta^{15} \mathrm{~N}$ values for migratory and resident Apogon notatus are shown in Table 2 . Their $\delta^{13} \mathrm{C}$ and $\delta^{15} \mathrm{~N}$ showed significant size dependence although there was no interaction with season or life history type $\left(\delta^{13} \mathrm{C}\right.$, month $\times$ SL: $p=0.60$, type $\times$ SL: $p=0.19$; $\delta^{15} \mathrm{~N}$, month $\times \mathrm{SL}: \mathrm{p}=0.23$, type $\times \mathrm{SL}: \mathrm{p}=$ $0.17)$. After adjusting for SL, ANCOVA revealed that their $\delta^{13} \mathrm{C}$ was significantly different among months $\left(F_{5,123}=26.0, \mathrm{p}<\right.$ 0.001 ) and between life history types $\left(F_{1,123}=15.4, \mathrm{p}<0.001\right)$. Immediately after returning from migration in March, the migratory type showed drastic depletion of $\delta^{13} \mathrm{C}$, being significantly different from that of the resident type (Table 2). Thereafter, the migratory type enriched its $\delta^{13} \mathrm{C}$, approaching that of the resident type in June. In October, when postbreeding fish formed large shoals, how-

distance for the clustering. Group A consisted of zooplanktivores and zoobenthivores, such as decapods, Chaetognatha and Clupeiformes juveniles, showing the highest $\delta^{15} \mathrm{~N}$ values. Group B consisted of mesozooplankton, such as planktonic gammarids, calanoid copepods and fish larvae. Group C consisted of hypoplankton, such as euphausiids and decapod larvae, and ever, a significant difference in $\delta^{13} \mathrm{C}$ between migratory and resident types was noted again (Table 2). By contrast, although size-adjusted $\delta^{15} \mathrm{~N}$ was significantly different among months (2-way ANCOVA, $F_{5,123}=17.0, \mathrm{p}<$ $0.001)$, there was no significant difference between migratory and resident types (2-way ANCOVA, $F_{1,123}=1.5$, $\mathrm{p}=0.2)$.

Table 2. Apogon notatus. $\delta^{13} \mathrm{C}$ and $\delta^{15} \mathrm{~N}$ (mean $\pm \mathrm{SD}$ ) for resident and migratory types of neritic individuals. p-values are for post hoc comparisons between life history types in each month using the contrast method. -: no data

\begin{tabular}{|c|c|c|c|c|c|c|c|c|}
\hline \multirow[t]{2}{*}{ Date } & \multicolumn{2}{|c|}{$-\delta^{13} \mathrm{C}(\%)$} & \multirow[t]{2}{*}{$F$} & \multirow[t]{2}{*}{$\mathrm{p}$} & \multicolumn{2}{|c|}{$\longrightarrow \delta^{15} \mathrm{~N}(\%)$} & \multirow[t]{2}{*}{$F$} & \multirow[t]{2}{*}{$\mathrm{p}$} \\
\hline & Resident & Migratory & & & Resident & Migratory & & \\
\hline \multicolumn{9}{|l|}{2003} \\
\hline October & $-15.9 \pm 0.2$ & $-16.2 \pm 0.3$ & 5.53 & 0.03 & $12.5 \pm 0.2$ & $12.3 \pm 0.4$ & 0.02 & 0.90 \\
\hline $\begin{array}{l}\text { December } \\
\mathbf{2 0 0 4}\end{array}$ & $-16.0 \pm 0.4$ & $-16.2 \pm 0.3$ & 3.09 & 0.09 & $13.0 \pm 0.3$ & $12.9 \pm 0.5$ & 1.24 & 0.28 \\
\hline February & $-16.5 \pm 0.2$ & - & & & $12.6 \pm 0.3$ & - & & \\
\hline March & $-16.6 \pm 0.2$ & $-16.9 \pm 0.1$ & 12.63 & $<0.01$ & $12.4 \pm 0.2$ & $12.2 \pm 0.2$ & 3.27 & 0.09 \\
\hline April & $-16.5 \pm 0.3$ & $-16.8 \pm 0.3$ & 3.46 & 0.08 & $12.6 \pm 0.4$ & $12.3 \pm 0.4$ & 2.19 & 0.15 \\
\hline June & $-16.2 \pm 0.2$ & $-16.1 \pm 0.2$ & 0.16 & 0.69 & $13.1 \pm 0.3$ & $13.3 \pm 0.3$ & 3.03 & 0.10 \\
\hline
\end{tabular}




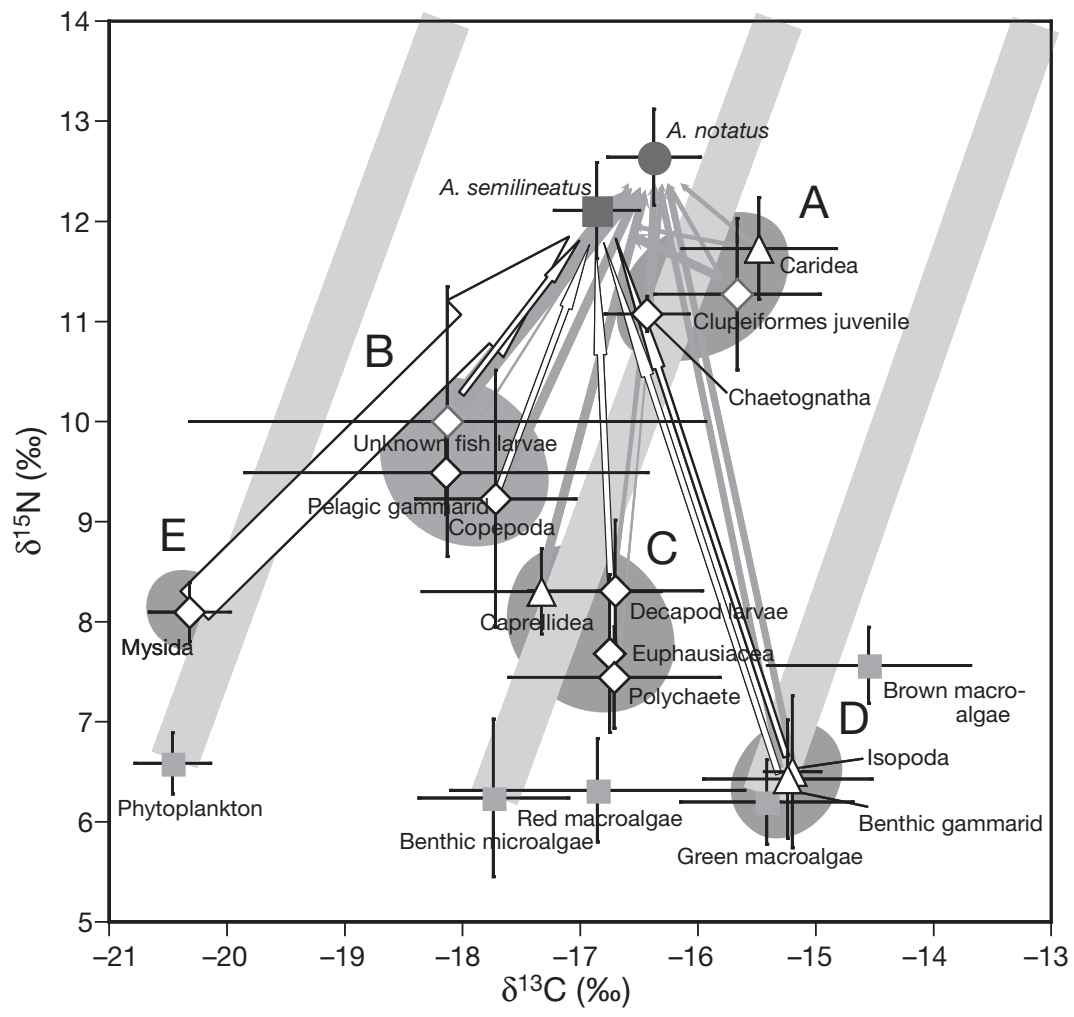

Fig. 4. Carbon and nitrogen isotopic signatures of Apogon notatus, A. semilineatus and their potential prey. Filled circle is for A. notatus and filled square for $A$. semilineatus. Open diamonds are for planktonic animals, open triangles for benthic animals and grey squares for primary producers. Dotted zones represent the hypothetical trophic pathway starting from each primary producer and exclusive reliance on it. Gammaridea was divided into planktonic and benthic groups. The grey and the white arrows represent the food sources of A. notatus and $A$. semilineatus, respectively. Arrow thickness represents the relative reliance on each prey of the 2 apogonids, as indicated by $\% W$ of their dietary data in Table 1. The prey were classified into 5 feeding functional Groups A through E. Vertical and horizontal bars are standard deviations

viduals showed markedly different isotopic signatures from each other (October: eigenvalue $=0.54$, canonical correlation $=0.59$, Wilk's $\lambda=0.65, \chi^{2}=8.17$, $\mathrm{p}=0.02$; December: eigenvalue $=0.13$, canonical correlation $=0.34$, Wilk's $\lambda=$ 0.88, $\chi^{2}=2.70, p=0.26$; Fig. 5).

Compared with the 2 life history types of the neritic Apogon notatus, the deepwater congener $A$. semilineatus showed a discrete distribution of its discriminant scores from December to April, whereas a large part of its distribution was overlapped from June to October (Fig. 5).

\section{DISCUSSION}

\section{Coastal food web}

The neritic species Apogon notatus and the deepwater species $A$. semilineatus utilized a variety of prey from 5 functional feeding groups in the coastal food web of Uwa Sea. Judging from the food web configuration on the isotope map (Fig. 4), Group E was regarded as pelagic primary consumers grazing on phytoplankton. Mysids are pelagic species but frequently occur near the bottom in deep waters and sometimes even in shallow waters (Viherluoto \& Viitasalo 2001). Although our mysid samples were collected in the neritic habitat, their isotopic signa-

In March, just after returning from the migration, isotopic signatures of Apogon notatus were effective in discriminating between the 2 life history types, being represented by the discriminant equation, $z=$ $-0.73 \delta^{15} \mathrm{~N}+0.27 \delta^{13} \mathrm{C}-18.79$ (eigenvalue $=0.76$, canonical correlation $=0.66$, Wilk's $\lambda=0.57, \chi^{2}=10.21$, $\mathrm{p}=0.006$ ). Incorrect discrimination rate was $19.0 \%$, suggesting that $19.0 \%$ of A. notatus inhabiting the breakwater might be migratory fish that newly settled there. Assuming such a misclassification rate, at least $45.0 \%$ of migratory fish in April had significantly different isotopic signatures from those of resident fish (eigenvalue $=0.32$, canonical correlation $=0.50$, Wilk's $\lambda=0.76, \chi^{2}=6.17, p=0.04$; Fig. 5). In June, however, these 2 life history types could not be discriminated by their isotopic signatures (eigenvalue $=0.10$, canonical correlation $=0.30$, Wilk's $\lambda=0.91, \chi^{2}=1.66, p=0.44$ ). In October and December, during which both types formed large shoals in the neritic habitat, some indi- ture suggests that they relied on a pelagic food chain while performing their vertical and horizontal migrations. Group C relied on the food chain starting from benthic microalgae. Although its isotopic distribution overlapped with the food chain starting from macroalgae, which showed a broad range of $\delta^{13} \mathrm{C}$, it was less likely that members of Group $\mathrm{C}$ grazed on macroalgae on the basis of their feeding morphology and behavior. In Group B $\delta^{15} \mathrm{~N}$ was enriched by 1 to $2 \%$ compared with that of Groups E and C, suggesting that this group consisted of omnivorous feeders that utilized both primary producers and primary consumers in their diet. Omnivorous feeding has been reported for some members of this group: e.g. calanoid copepods (Kleppel 1993) and fish larvae (Lehtiniemi et al. 2007). Group B was positioned between Groups $\mathrm{E}$ and $\mathrm{C}$ in terms of $\delta^{13} \mathrm{C}$, probably reflecting its mixed reliance on products derived from phytoplankton and benthic microalgae. 

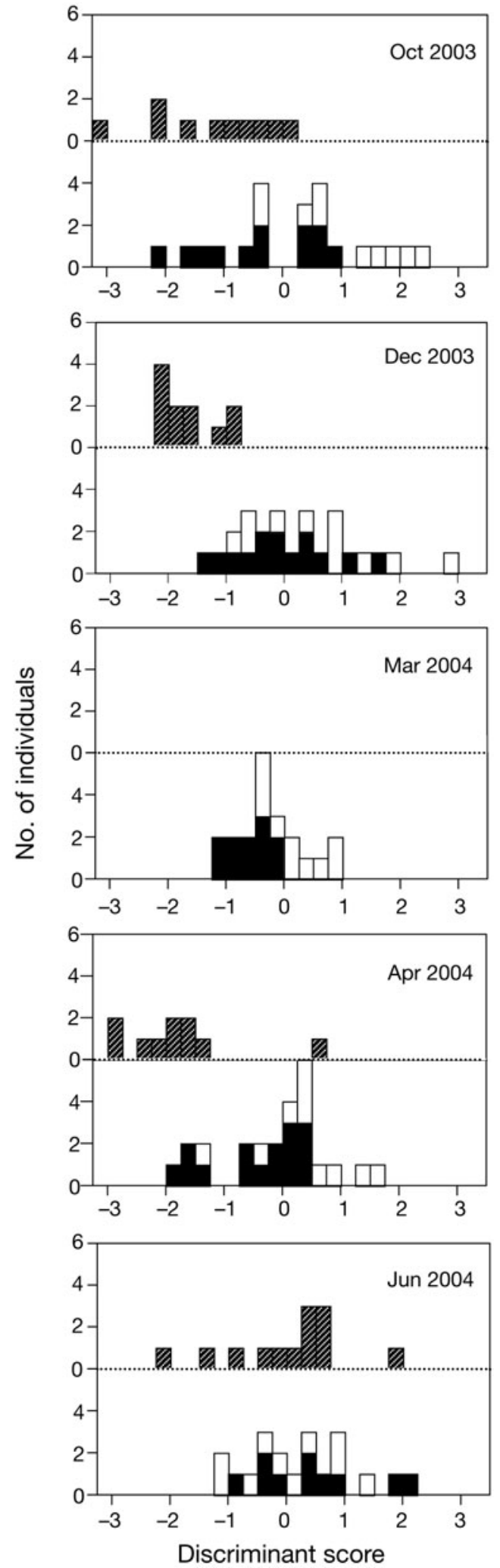

Fig. 5. Seasonal changes in frequency distribution of discriminant scores for migratory (black bars) and resident (white bars) types of neritic Apogon notatus (lower panels) and for deepwater $A$. semilineatus (hatched bars in upper panels)
Group D is typical of benthic herbivores-detritivores. Although its potential food could not be identified, its carbon source might be macroalgal derived matter because of its similarity to macroalgal $\delta^{13} \mathrm{C}$. In general, organic matter in the sediment is more depleted in $\delta^{15} \mathrm{~N}$ than newly produced organic matter due to decomposition (Lehmann et al. 2002). This may be the reason for the more depleted $\delta^{15} \mathrm{~N}$ in these benthic detritivores.

Group A was located on the hypothetical food chain starting from benthic microalgae and its $\delta^{15} \mathrm{~N}$ was higher by 3 to $4 \%$ o than that of Group C, suggesting that Group A members are secondary consumers feeding on benthic primary consumers. Apogon notatus is also located near the hypothetical benthic food chain. Assuming that Groups E and $\mathrm{C}$ are purely primary consumers, the trophic level of $A$. notatus was estimated at 3.4 and that of $A$. semilineatus at 3.2, which were calculated from the difference in $\delta^{15} \mathrm{~N}$ between the focal species and the basal food (i.e. the primary consumers). The slightly lower trophic level of $A$. semilineatus relative to that of $A$. notatus would be due to its tendency to feed exclusively on mysids, which are pelagic primary consumers. This also accords with the more depleted $\delta^{13} \mathrm{C}$ in $A$. semilineatus, suggesting its reliance on pelagic primary production as its carbon source. However, A. semilineatus showed seasonal variation in isotopic composition, as shown in Fig. 5. Azeta et al. (1983) reported that A. semilineatus migrates from deep to shallow waters for several months of its summer breeding season, which supports our finding that the isotopic signature of $A$. semilineatus approached that of $A$. notatus toward the summer season and changed from the neritic characteristics toward the winter season.

In coastal ecosystems benthic microalgae generally play an important part in primary production in the shallow, euphotic layer (Borum \& Sand-Jensen 1996, Jahnke et al. 2000, Takai et al. 2002, Okuda et al. 2004), whereas phytoplankton is the major carbon source for benthic communities in the deep, aphotic layer (McGlathery et al. 2001, Gazeau et al. 2004). Our stable isotope analysis suggests that Apogon notatus is supported by benthic primary products in the neritic habitat and A. semilineatus by pelagic primary products in the deepwater habitat, highlighting the spatial heterogeneity of the coastal food web structure. In another view temporal variation in isotopic composition of neritic $A$. notatus and deepwater A. semilineatus suggests that their migratory nature seasonally couples these 2 habitats in the coastal ecosystem. Our comparative approach also stresses that coastal migratory animals play an important role in material cycling and habitat coupling within the coastal ecosystems. 


\section{Life history polymorphism}

The present isotope study also revealed the existence of a discontinuous individual variation in $\delta^{13} \mathrm{C}$, which was ascribed to seasonal migration patterns within a population of Apogon notatus, though some part $(19.0 \%)$ of the variation might have been accounted for by an artifact of misclassification. Immediately after returning to the neritic breeding ground, $\delta^{13} \mathrm{C}$ of the migratory type was more depleted than that of the resident type, approaching that of deepwater $A$. semilineatus. In large animals there is usually a time lag between feeding shift and isotopic change in tissues (Hesslein et al. 1993). Particularly in fishes the degree of delayed isotopic response to the feeding shift greatly depends on the rate of tissue accumulation during growth but not on the metabolic turnover rate (Herzka \& Holt 2000, Maruyama et al. 2001). In small fish, such as A. notatus, isotope turnover rates are usually estimated as a few months (Hesslein et al. 1993, Herzka 2005). Therefore, the depletion of $\delta^{13} \mathrm{C}$ in the migratory fish might be because they stayed and grew for 1 to $3 \mathrm{mo}$ in winter in pelagic waters. The winter depletion of $\delta^{13} \mathrm{C}$ was also found in resident $A$. notatus. This depletion may be because they frequently fed on planktonic prey, such as copepods and fish larvae, which have relatively low $\delta^{13} \mathrm{C}$ associated with phytoplankton production, in the neritic habitat during winter. However, their feeding habits were not different from those of the migratory type after territory settlement, and the $\delta^{13} \mathrm{C}$ values of both types converged, increasing their reliance on benthic production. Judging from these isotopic results, we conclude that a large number of $A$. notatus individuals would live in pelagic waters, probably in the deep layer, during winter migration.

It has been also reported that the Australian cardinalfish Apogon rueppellii move to offshore deeper waters during winter months and return to inshore shallow waters to breed in the following spring (Chrystal et al. 1985). In temperate coastal waters the winter air cools down the upper layer rapidly, resulting in reversal of the vertical gradient of water temperature (Sims et al. 2004). Since water temperature is a powerful controlling factor of metabolic demand and assimilation efficiency in ectotherms, fish adapt by staying under their optimal temperature regime to minimize physiological cost (Clarke 2003). In Pacific herring and cod, gonadal development depends on daily water temperature (Ware \& Tanasichuk 1989, Hutchings \& Myers 1994). For such physiological reasons some coastal fishes migrate from neritic to deepwater habitat during the winter season in favor of warm water temperature (Hutchings \& Myers 1994, Cote et al. 2004, Sims et al. 2004).
There are other possible mechanisms for the winter migration to deep waters, including salinity (Chrystal et al. 1985), food availability (Sogard \& Olla 1996) and refuge from physical turbulence due to stormy weather (Chrystal et al. 1985). Chrystal et al. (1985) found that winter migration of Apogon rueppellii is associated with changes in water temperature and salinity. In A. notatus, a large number of individuals emigrated from the neritic habitat when the average water temperature was below $20^{\circ} \mathrm{C}$. However, there was no remarkable vertical gradient of salinity in Uwa Sea and feeding intensity of neritic A. notatus was high throughout the non-breeding season (Okuda 2001), suggesting its high food availability in the present study population. Thus, water temperature may be one of the most important factors facilitating the migration of $A$. notatus to deep waters in winter.

As revealed by the stable isotope analysis of Apogon notatus, discontinuous intraspecific variation in isotopic signatures has been reported in some fish species (e.g. coregonus: Hesslein et al. 1993; blue tilapia: Gu et al. 1997; bluegill sunfish: Ehlinger 1990, Uchii et al. 2007). Such an isotopic variation is attributable to resource-based trophic polymorphisms within a population. In A. notatus, by contrast, the isotopic discontinuity was due to the seasonal difference in life history pattern (i.e. migration or residence) among individuals rather than due to sympatric food resource partitioning. This is often the case in diadromous (i.e. migrating between marine and freshwater ecosystems at a certain stage of life history) fishes (Kline et al. 1993, Doucett et al. 1999b) and in non-diadromous coastal fishes (e.g. Atlantic cod: Cote et al. 2004; black bream: Elsdon \& Gillanders 2006; snapper: Hamer et al. 2006; bluefish: Shepherd et al. 2006). In many diadromous species, there exists intrapopulation variation in the life history pattern. In salmonids, for example, most populations consist of both anadromous (sea-run migratory) and non-anadromous (freshwater resident) types (Doucett et al. 1999a,c, McCarthy \& Waldron 2000, Charles et al. 2006, Morinville \& Rasmussen 2006). By contrast, the present study population of A. notatus had 2 life history types: one migrates between neritic and deepwater habitats in winter (i.e. migratory type) and the other resides in the neritic habitat throughout the year (i.e. resident type). Our stable isotope analysis succeeded in detecting seasonal isotopic differences between these 2 life history types, focusing on isotopic differences in the baseline between neritic and deepwater food webs in the coastal ecosystem.

Interestingly, some of the migratory type had a different $\delta^{13} \mathrm{C}$ from that of the resident type before migration. Although such a difference may be accrued by chance as a result of misclassification, this can be 
partly ascribed to the difference in feeding habits during their sympatric period in winter, as also shown by the dietary analysis (Fig. 3). This implies that each type inclined to specialize its feeding habits prior to winter migration. It is still unclear whether such a feeding specialization caused individual variation of life history pattern as phenotypic plasticity or whether it represents a contingent strategy leading to a life history divergence within a population (Secor 1999). Future research should focus on elucidating to what extent life history polymorphism is common among coastal fishes and what its mechanism is for the expression and maintenance of different life history morphs within a population.

Acknowledgements. We are grateful to 2 anonymous reviewers for comments. The present study was financially supported by the 21st Century COE Program of the Ministry of Education, Culture, Sports, Science and Technology, Japan. N.O. was supported by the Grant for Biodiversity Research of the 21st Century COE (A14).

\section{LITERATURE CITED}

Azeta M, Ikemoto R, Sudo H, Azuma M (1983) Feeding habits of a cardinal fish, Apogon semilineatus, in Shijiki Bay (Hirado Island, Nagasaki Pref.) laying stress on relationships to 0-group red seabream (Pagrus major). Bull Seikai Reg Fish Res Lab 59:85-99

Borum J, Sand-Jensen K (1996) Is total primary production in shallow coastal marine waters stimulated by nitrogen loading? Oikos 76:406-410

Bradstreet MSW (1980) Thick-billed murres and black guillemots in the Barrow Strait area, NWT, during spring: diets and food availability along ice edges. Can J Zool 58: $2130-2140$

Burton RK, Koch PL (1999) Isotopic tracking of foraging and long-distance migration in northeastern Pacific pinnipeds. Oecologia 119:578-585

> Charles K, Roussel JM, Lebel JM, Baglinière JL, Ombredane D (2006) Genetic differentiation between anadromous and freshwater resident brown trout (Salmo trutta L.): insights obtained from stable isotope analysis. Ecol Freshw Fish 15:255-263

> Cherel Y, Hobson KA, Weimerskirch H (2000) Using stableisotope analysis of feathers to distinguish moulting and breeding origins of seabirds. Oecologia 122:155-162

Chrystal PJ, Potter IC, Loneragan NR, Holt CP (1985) Age structure, growth rates, movement patterns and feeding in an estuarine population of the cardinalfish Apogon rueppellii. Mar Biol 85:185-197

Clarke A (2003) Costs and consequences of evolutionary temperature adaptation. Trends Ecol Evol 18:573-580

Cote D, Moulton S, Frampton PCB, Scruton DA, McKinley RS (2004) Habitat use and early winter movements by juvenile Atlantic cod in a coastal area of Newfoundland. J Fish Biol 64:665-679

> Cunjak RA, Roussel JM, Gray MA, Dietrich JP, Cartwright DF, Munkittrick KR, Jardine TD (2005) Using stable isotope analysis with telemetry or mark-recapture data to identify fish movement and foraging. Oecologia 144: 636-646

DeNiro MJ, Epstein S (1978) Influence of diet on the distribu- tion of carbon isotopes in animals. Geochim Cosmochim Acta 42:495-506

DeNiro MJ, Epstein S (1981) Influence of diet on the distribution of nitrogen isotopes in animals. Geochim Cosmochim Acta 45:341-351

Doucett RR, Hooper W, Power G (1999a) Identification of anadromous and non-anadromous adult brook trout and their progeny in the Tabusintac River, New Brunswick, by means of multiple-stable-isotope analysis. Trans Am Fish Soc 128:278-288

> Doucett RR, Booth RK, Power G, McKinley RS (1999b) Effects of the spawning migration on the nutritional status of anadromous Atlantic salmon (Salmo salar): insights from stableisotope analysis. Can J Fish Aquat Sci 56: 2172-2180

> Doucett RR, Power M, Power G, Caron F, Reist JD (1999c) Evidence for anadromy in a southern relict population of Arctic charr from North America. J Fish Biol 55:84-93

- Ehlinger TJ (1990) Habitat choice and phenotype-limited feeding efficiency in bluegill: individual differences and trophic polymorphism. Ecology 71:886-896

Elsdon TS, Gillanders BM (2006) Identifying migratory contingents of fish by combining otolith Sr:Ca with temporal collections of ambient Sr:Ca concentrations. J Fish Biol 69:643-657

France RL (1995a) Carbon-13 enrichment in benthic compared to planktonic algae: foodweb implications. Mar Ecol Prog Ser 124:307-312

France RL (1995b) Differentiation between littoral and pelagic food webs in lakes using stable carbon isotopes. Limnol Oceanogr 40:1310-1313

France RL, Peters RH (1997) Ecosystem differences in the trophic enrichment of ${ }^{13} \mathrm{C}$ in aquatic food webs. Can J Fish Aquat Sci 54:1255-1258

Fry B, Sherr EB (1984) $\delta^{13} \mathrm{C}$ measurements as indicators of carbon flow in marine and freshwater ecosystems. Contrib Mar Sci 27:13-47

Gaston AJ, Nettleship DN (1981) The thick-billed murres of Prince Leopold Island. Monograph Series No. 6, Canadian Wildlife Service, Ottawa

Gazeau F, Smith SV, Gentili B, Frankignoulle M, Gattuso JP (2004) The European coastal zone: characterization and first assessment of ecosystem metabolism. Estuar Coast Shelf Sci 60:673-694

Gu B, Schelske CL, Hoyer MV (1997) Intrapopulation feeding diversity in blue tilapia: evidence from stable-isotope analyses. Ecology 78:2263-2266

- Hamer PA, Jenkins GP, Coutin P (2006) Barium variation in Pagrus auratus (Sparidae) otoliths: a potential indicator of migration between an embayment and ocean waters in south-eastern Australia. Estuar Coast Shelf Sci 68: $686-702$

Hansson S, Hobbie JE, Elmgren R, Larsson U, Fry B, Johansson $\mathrm{S}$ (1997) The stable nitrogen isotope ratio as a marker of food-web interactions and fish migration. Ecology 78 : 2249-2257

Hecky RE, Hesslein RT (1995) Contributions of benthic algae to lake food webs as revealed by stable isotope analyses. J N Am Benthol Soc 14:631-653

> Herzka SZ (2005) Assessing connectivity of estuarine fishes based on stable isotope ratio analysis. Estuar Coast Shelf Sci 64:58-69

Herzka SZ, Holt GJ (2000) Changes in isotopic composition of red drum (Sciaenops ocellatus) larvae in response to dietary shifts: potential applications to settlement studies. Can J Fish Aquat Sci 57:137-147

Hesslein RH, Hallard KA, Ramlal P (1993) Replacement of sulfur, carbon, and nitrogen in tissue of growing broad white- 
fish (Coregonus nasus) in response to a change in diet traced by $\delta^{34} \mathrm{~S}, \delta^{13} \mathrm{C}$, and $\delta^{15} \mathrm{~N}$. Can J Fish Aquat Sci 50:2071-2076

> Hicks BJ, Wipfli MS, Lang DW, Lang ME (2005) Marinederived nitrogen and carbon in freshwater-riparian food webs of the Copper River Delta, southcentral Alaska. Oecologia 144:558-569

Hobson KA (1999) Tracing origins and migration of wildlife using stable isotopes: a review. Oecologia 120:314-326

Hobson KA, Clark RG (1992) Assessing avian diets using stable isotopes I: turnover of ${ }^{13} \mathrm{C}$ in tissues. Condor 94: 181-188

Hutchings JA, Myers RA (1994) Timing of cod reproduction: interannual variability and the influence of temperature. Mar Ecol Prog Ser 108:21-31

Jahnke RA, Nelson JR, Marinelli RL, Eckman JE (2000) Benthic flux of biogenic elements on the southeastern US continental shelf: influence of pore water advective transport and benthic microalgae. Cont Shelf Res 20:109-127

Kleppel GS (1993) On the diets of calanoid copepods. Mar Ecol Prog Ser 99:183-195

Kline TC Jr, Goering JJ, Mathisen OA, Poe PH, Parker PL, Scalan RS (1993) Recycling of elements transported upstream by runs of Pacific salmon: II. $\delta^{15} \mathrm{~N}$ and $\delta^{13} \mathrm{C}$ evidence in the Kvichak River Watershed, Bristol Bay, southwestern Alaska. Can J Fish Aquat Sci 50:2350-2365

Lehmann MF, Bernasconi SM, Barbieri A, McKenzie JA (2002) Preservation of organic matter and alternation of its carbon and nitrogen isotope composition during simulated and in situ early sedimentary diagenesis. Geochim Cosmochim Acta 66:3573-3584

Lehtiniemi M, Hakala T, Saesmaa S, Viitasalo M (2007) Prey selection by the larvae of three species of littoral fishes on natural zooplankton assemblages. Aquat Ecol 41:85-94

Maruyama A, Yamada Y, Rusuwa B, Yuma M (2001) Change in stable nitrogen isotope ratio in the muscle tissue of a migratory goby, Rhinogobius sp., in a natural setting. Can J Fish Aquat Sci 58:2125-2128

McCarthy ID, Waldron S (2000) Identifying migratory Salmo trutta using carbon and nitrogen stable isotope ratios. Rapid Commun Mass Spectrom 14:1325-1331

> McGlathery KJ, Anderson AC, Tyler AC (2001) Magnitude and variability of benthic and pelagic metabolism in a temperate coastal lagoon. Mar Ecol Prog Ser 216:1-15

Michener RH, Schell DM (1994) Stable isotope ratios as tracers in marine aquatic food webs. In: Lajtha K, Michener RH (eds) Stable isotopes in ecology and environmental science. Blackwell Scientific Publications, Oxford, p 137-157

Minagawa M, Wada E (1984) Stepwise enrichment of ${ }^{15} \mathrm{~N}$ along food chains: further evidence and the relation between $\delta^{15} \mathrm{~N}$ and animal age. Geochim Cosmochim Acta 48:1135-1140

Morinville GR, Rasmussen JB (2006) Does life-history variability in salmonids affect habitat use by juveniles? A comparison among streams open and closed to anadromy. J Anim Ecol 75:693-704

> Okuda N (1999) Sex roles are not always reversed when the

Editorial responsibility: Matthias Seaman, Oldendorf/Luhe, Germany potential reproductive rate is higher in females. Am Nat 153:540-548

Okuda N (2001) The costs of reproduction to males and females of a paternal mouthbrooding cardinalfish Apogon notatus. J Fish Biol 58:776-787

Okuda N, Hamaoka H, Fukumoto T, Miyasaka H, Omori K (2004) How to monitor the coastal food-web dynamics using stable-isotope analysis of higher consumers. In: Takeoka H, Sugimoto T (eds) Proc Int Symp Long-term Variations in Coastal Environments and Ecosystems, 27-28 Sep 2004, Matsuyama, Japan. Ehime University, Matsuyama, p 200-205

> Peterson BJ, Fry B (1987) Stable isotopes in ecosystem studies. Annu Rev Ecol Syst 18:293-320

Secor DH (1999) Specifying divergent migrations in the concept of stock: the contingent hypothesis. Fish Res 43: 13-34

Shepherd GR, Moser J, Deuel D, Carlsen P (2006) The migration patterns of bluefish (Pomatomus saltatrix) along the Atlantic coast determined from tag recoveries. Fish Bull (Wash DC) 104:559-570

Sims DW, Wearmouth VJ, Genner MJ, Southward AJ, Hawkins SJ (2004) Low-temperature-driven early spawning migration of a temperate marine fish. J Anim Ecol 73:333-341

Sogard SM, Olla BL (1996) Food deprivation affects vertical distribution and activity of a marine fish in a thermal gradient: potential energy-conserving mechanisms. Mar Ecol Prog Ser 133:43-55

Takai N, Mishima Y, Yorozu A, Hoshika A (2002) Carbon sources for demersal fish in the western Seto Inland Sea, Japan, examined by $\delta^{13} \mathrm{C}$ and $\delta^{15} \mathrm{~N}$ analyses. Limnol Oceanogr 47:730-741

Tieszen LL, Boutton TW (1988) Stable carbon isotopes terrestrial ecosystem research. In: Rundel PW, Ehleringer JR, Nagy KA (eds) Stable isotopes in ecological research. Springer, Berlin, Heidelberg, New York, p 167-195

Uchii K, Okuda N, Yonekura R, Karube Z, Matsui K, Kawabata Z (2007) Trophic polymorphism in bluegill sunfish (Lepomis macrochirus) introduced into Lake Biwa: evidence from stable isotope analysis. Limnology 8:59-63

Vander Zanden MJ, Rasmussen JB (1999) Primary consumer $\delta^{13} \mathrm{C}$ and $\delta^{15} \mathrm{~N}$ and the trophic position of aquatic consumers. Ecology 80:1395-1404

Viherluoto M, Viitasalo M (2001) Effect of light on the feeding rates of pelagic and littoral mysid shrimps: a trade-off between feeding success and predation avoidance. J Exp Mar Biol Ecol 261:237-244

Ware DM, Tanasichuk RW (1989) Biological basis of maturation and spawning waves in Pacific herring (Clupea harengus pallasi). Can J Fish Aquat Sci 46:1776-1784

> Webster MS, Marra PP, Haig SM, Bensch S, Holmes RT (2002) Links between worlds: unraveling migratory connectivity. Trends Ecol Evol 17:76-83

> Wissel B, Fry B (2005) Tracing Mississippi River influences in estuarine food webs of coastal Louisiana. Oecologia 144:659-672

Submitted: July 6, 2007; Accepted: January 11, 2008

Proofs received from author(s): June 4, 2008 